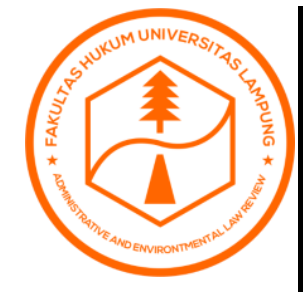

ADMINISTRATIVE AND ENVIRONMENTAL LAW REVIEW

Volume 2 Issue 1, January-June 2021: PP: 11-20

Faculty of Law, Universitas Lampung, Bandar Lampung, Indonesia.

http://jurnal.fh.unila.ac.id/index.php/aelr

P-ISSN: 2723-2484

E-ISSN: $2745-9330$

\title{
The Prosecutor's Authority to Conduct a Criminal Investigation Based on The Government Administration Law
}

\author{
Leonardo Adiguna \\ leonardoadiguna@gmail.com \\ Kejaksaan Negeri Pringsewu, Indonesia
}

Submitted: 13 January 2021; Reviewed: 30 January 2021; Accepted: 30 April 2021

\begin{tabular}{|c|c|}
\hline Article's Information & Abstract \\
\hline $\begin{array}{l}\text { Keywords: Prosecutor's; Authority; } \\
\text { Administration; Criminal. } \\
\text { DOI: } \\
\text { https://doi.org/10.25041/aelr.v2i1.2214 }\end{array}$ & $\begin{array}{l}\text { This research uses a normative approach, } \\
\text { which is carried out by examining laws and } \\
\text { theories. Also, this study uses a case approach, } \\
\text { namely the } 2017 \text { village fund corruption case } \\
\text { in Pekon Sukaratu. The main problem in this } \\
\text { research is what is the authority of the } \\
\text { prosecutor in conducting investigations into } \\
\text { criminal acts of corruption after the passage of } \\
\text { Law Number } 30 \text { of } 2014 \text { concerning } \\
\text { Government Administration and whether the } \\
\text { investigation carried out by the prosecutor at } \\
\text { the Pringsewu District Prosecutor's Office in } \\
\text { coordination with the Government Internal } \\
\text { Supervisory Apparatus or Aparatur Pengawas } \\
\text { Internal Pemerintah (APIP) against the } \\
\text { allegations a criminal act of corruption in the } \\
\text { management of village funds in } 2017 \text { in Pekon } \\
\text { Sukaratu whose losses to the state have been } \\
\text { returned have met the principle of legal } \\
\text { certainty. The research results show that the } \\
\text { prosecutor has the authority to carry out the } \\
\text { law enforcement process, namely the } \\
\text { investigation of suspected corruption crimes as } \\
\text { stipulated in Article } 30 \text { paragraph (1) letter } \\
\text { of the law on the Prosecutor's Office of the } \\
\text { Republic of Indonesia. Based on the results of } \\
\text { the research that has been done, it is better if } \\
\text { changes in laws and regulations related to the }\end{array}$ \\
\hline
\end{tabular}

Administrative and Environmental Law Review is a journal published by Faculty of Law,

Universitas Lampung, under a Creative Commons Attribution-ShareAlike 4.0

International License. 
elements of corruption in Law No. 31 of 1999 concerning Eradication of Corruption Crime because there is a product of the Constitutional Court with the decision No. 25/PUU-XIV/2016. Besides, there is a need for socialization for prosecutors regarding their authority in TPK investigations and related to coordination patterns with the authority of APIP in carrying out investigations and calculating state financial losses.

\section{A. Introduction}

The authority of prosecutors as investigators of certain crimes is under statutory provisions, namely Article 30 Paragraph (1) letter d of Law Number 16 of 2004 concerning the Republic of Indonesia Attorney General's Office (RI Attorney Law), which states that the Attorney General has the duty and authority to investigate corruption under the law. ${ }^{1}$ In an integrated criminal law enforcement system or ICJS (Integrated Criminal Justice System), investigations are integrated with investigations so that if the prosecutor has the authority to investigate based on Article 30 Paragraph (1) letter $d$ of the law on the Indonesian Prosecutor's Office such as investigating criminal acts of corruption Likewise, the Prosecutor's Office also has the authority to carry out investigations into TPK. ${ }^{2}$ The investigation has the meaning of a series of investigators finding and looking for evidence to make light of a criminal event. The investigation's meaning is a series of actions by the investigator to find and find an event that is suspected of being a criminal act. ${ }^{3}$ Based on the meaning of investigation and investigation in KUHAP alone, they are interrelated and form an inseparable unit. Law No. 30 of 2014 concerning Government Administration (from now on referred to as the AP Law) is one of the progressive regulations that provide the latest impact and composition of bureaucratic reform and proper governance.

Law No. 30 of 2014 is one of the bases for good governance (good government) to establish good relations between government officials and the community. The government bureaucracy is good and effective. ${ }^{4}$ Abuse based on juridical aspects of Article 17 Paragraph (1) of Law no. 30 of 2014, there is a prohibition against government agencies or officials from abusing authority. Then Article 17 Paragraph (2) of the AP Law contains 3 (three) qualifications of abuse of power, namely:

1) Exceeding authority is a decision or action or action of a government agency/official that exceeds the term of office or the time limit for the validity of authority or exceeds the territorial limits of the validity of authority and/or is contrary to the provisions of statutory regulations (Article 18 Paragraph (1) of the AP Law);

\footnotetext{
${ }^{1}$ Mohammad Sahlan, "Kewenangan Peradilan Tipikor Pasca Berlakunya Undang-Undang No. 30 Tahun 2014 Tentang Administrasi Pemerintahan," Arena Hukum 9, no. 2 (2016): 166-89, https://doi.org/10.21776/ub.arenahukum.2016.00902.2.

2 Vani Kurnia, Sahuri Lasmadi, and Elizabeth Siregar, "Tinjauan Yuridis Terhadap Tugas Dan Kewenangan Jaksa Sebagai Penyidik Dalam Perkara Tindak Pidana Korupsi 2020,” Pampas Journal of Criminal Law 1, no. 3 (2020): 1-11, https://online-journal.unja.ac.id/Pampas/article/view/11084.

${ }^{3}$ Disiplin F. Manao, "Penyelesaian Penyalahgunaan Wewenang Oleh Aparatur Pemerintah Dari Segi Hukum Administrasi Dihubungkan Dengan Tindak Pidana Korupsi," Jurnal Wawasan Yuridika 2, no. 1 (March 31, 2018): 1, https://doi.org/10.25072/jwy.v2i1.158.

${ }^{4}$ Marojahan Panjaitan, "PENYELESAIAN PENYALAHGUNAAN WEWENANG YANG MENIMBULKAN KERUGIAN NEGARA MENURUT HUKUM ADMINISTRASI PEMERINTAHAN," Jurnal Hukum IUS QUIA IUSTUM 24, no. 3 (July 2017): 431-47, https://doi.org/10.20885/iustum.vol24.iss3.art5.
} 
2) Mixing up authority means decisions or actions or actions of government bodies or officials that are outside the scope of the field or material of the authority given; and/or contrary to the purpose of the authority given (Article 18 Paragraph (2) of the AP Law);

3) Acting arbitrarily is a decision or action or action without the basis of authority; and/or contrary to a Court Decision which has permanent legal force (Article 18 Paragraph (3) of the AP Law).

That there is an Agreement dated 28 February 2018 (MoU) regarding the Coordination of the Government Internal Supervisory Apparatus (APIP). The agreement states that APIP plays the role of investigative examination/investigation of government officials who commit administrative errors. Likewise, if the prosecutor's office and the police receive a public report and an investigation is carried out, there is an administrative error. It can be submitted to APIP. However, suppose the APIP conducting the examination finds indications of suspected corruption. In that case, it can be submitted to the prosecutor's office or police for further action (Article 7 Paragraph (2), (3) and (4) Cooperation Agreement of the Ministry of Home Affairs, Attorney General's Office and Police dated 28 February 2018). APIP plays an important role in government administration supervision, one of which is in financial supervision that has the potential for state financial losses resulting from the abuse of authority in the perspective of an administrative approach. This is based on Article 20 Paragraph (4) and Article 70 Paragraph (3) Law no. 30 of 2014, which states that if the APIP examination finds state losses, it can be returned within 10 (ten) working days after the loss is found. The prosecutor team has implemented this at the Pringsewu District Prosecutor's Office.

At the Pringsewu District Prosecutor's Office, there is an investigation into village funds' corruption crime. Based on the investigation, Sprint Print-07/N.8.16.8/Fd.1/08/2018 on 16 August 2018 signed by the Head of the Pringsewu District Prosecutor's Office, investigative Prosecutor Team conducted an investigation signed on into the alleged TPK of village funds and the allocation of village funds to Pekon Sukaratu, Pagelaran District, Pringsewu Regency. The Pringsewu District Prosecutors' Team of Investigating Prosecutors found allegations of illegal acts that indicated the alleged TPK against Village Funds and Village Fund Allocation. These findings were carried out in coordination with the Government Internal Supervisory Apparatus or Aparat Pengawas Internal Pemerintah (APIP), namely Pringsewu Regency's Inspectorate, which based on the examination there were state losses that had to be returned by the head of the pekon or village head. When the state losses had been recovered (state losses were not there) because after the passing of Law No.30 of 2014, there is a return of state losses, so the investigation stage is stopped by the investigating team Pringsewu District Attorney.

Based on the description above, the problem to be investigated is what is the authority of the prosecutor in investigating criminal acts of corruption after the passage of Law Number 30 of 2014 concerning Government Administration and whether the prosecutor carried out the investigation at the Pringsewu District Prosecutor's Office in coordination with APIP against allegations of corruption in the management of village funds in 2017 in Pekon Sukaratu whose state losses have been returned has fulfilled the principle of legal certainty. The research method used in this research is the normative approach method, which is carried out by examining laws and theories, where normative research is library research. Also, this study uses juridical research, which examines the function of law or a rule in its application in the community, using a case approach, namely the corruption case of village funds in 2017 in Pekon Sukaratu. 


\section{B. Discussion}

1. The Authority of Prosecutors to Investigate Criminal Acts of Corruption After Law No. 30 of 2014 concerning Government Administration

The investigation is an attempt to find a criminal event and search for evidence in a criminal act. ${ }^{5}$ The law enforcement system against criminal acts with an integrated system or Integrated Criminal Justice System (ICJS) investigation is an integral part of the investigation itself. $^{6}$ Suppose the investigation is a series of actions to find a criminal event. In that case, the investigation based on Article 1 paragraph 2 of the Criminal Procedure Code of investigation is a business activity to find and collect evidence that sheds light on the criminal act that occurred and found the suspect.

The authority of investigation and investigation cannot stand alone, but instead, support each other and become one unit as a law enforcement system which the Indonesian Attorney carries out, one of which is based on Article 30 Paragraph (1) of Law No. 16 of 2004 concerning the RI Attorney General's Office. Then the Constitutional Court considered its decision, namely Article 30 Paragraph (1) letter d of the law on the prosecution, only providing entry points that open up opportunities for legislators to give the authority to conduct investigations to the Prosecutor's Office in certain laws. ${ }^{7}$

The power of the prosecutor to conduct investigations and investigations is also contained in the transitional regulation of Article 284 Paragraph (2) of the Criminal Procedure Code, which states that there are provisions for 2 (two) years after this KUHAP is ratified. ${ }^{8}$ So there are exceptions to the provisions specifically for criminal procedural law, namely investigation of the TPK, which among others is regulated in the Law on Investigation, Prosecution and Economic Crime Justice (Law Number 7 Drt. 1955) and the Law on Eradicating Corruption Crime or Tindak Pidana Korupsi (TPK) (Law Number 3 of 1971). ${ }^{9}$ In the context of jurisprudence, there is a verdict on the TPK case at the Supreme Court Number 1205 $\mathrm{K} / \mathrm{Pid} / 2003$ dated 10 October 2005, in a corruption case on behalf of the defendant Ade Rachlan whom the Ciamis Prosecutor charged with violating Article 9 in conjunction with Article 18 of Law No. 31 of 1999 in conjunction with Article 416 of the Criminal Code in conjunction with Article 55 Paragraph (1) of the 1 Criminal Code in conjunction with Article 64 Paragraph (1) of the Criminal Code which contains judges' considerations that state prosecutors have the duty and authority to carry out investigations, investigations, and prosecutions of TPK. ${ }^{10}$ The government's statement in the Constitutional Court Decision

\footnotetext{
5 Sutrisno Sutrisno and Ibnu Artadi, "IMPLEMENTASI PENEGAKKAN HUKUM TINDAK PIDANA KORUPSI PASCA BERLAKUNYA UU NO 30 TAHUN 2014 TENTANG ADMINISTRASI PEMERINTAHAN," HERMENEUTIKA : Jurnal Ilmu Hukum 3, no. 2 (September 28, 2019), https://doi.org/10.33603/hermeneutika.v3i2.2600.

6 Andhy Hermawan Bolifaar and Henry Dianto Pardamean Sinaga, "Managing Evidence of Tax Crime in Indonesia: An Artificial Intelligence Approach in Integrated Criminal Justice System," A Y E R JOURNAL 27, no. 1 (October 5, 2020): 143-58, https://doi.org/10.1445/AYERJOURNAL.V27I1.128.

${ }^{7}$ Constitutional Court Decision No. 28/PUU-V/2007, pg 99

${ }^{8}$ Gratia Debora Mumu, "KEWENANGAN JAKSA SEBAGAI PENYIDIK TINDAK PIDANA KORUPSI 1 Oleh: Gratia Debora Mumu 2,” LEX ADMINISTRATUM, vol. 4, March 16, 2016, https://ejournal.unsrat.ac.id/index.php/administratum/article/view/11503.

${ }^{9}$ Eka Yuliastuti and Iain Metro, "AL-WATHAN: Jurnal Ilmu Syariah PROBLEMATIKA YANG DIHADAPI JAKSA DALAM PENYIDIKAN TINDAK PIDANA KORUPSI (Studi Kasus Pada Kejaksaan Negeri Karanganyar)," Al-Wathan: Jurnal Ilmu Syariah, vol. 1, January 8, 2020, https://jurnal.stisda.ac.id/index.php/wathanDOI:https://doi.org/.

10 Zulkarnaen Zulkarnaen, Zainal Asikin, and Amiruddin Amiruddin, "Penyalahgunaan Wewenang Dalam Tindak Pidana Korupsi Setelah Berlakunya UU No. 30 Tahun 2014 Tentang Administrasi Pemerintahan," JESS (Journal of Education on Social Science) 4, no. 1 (June 1, 2020): 53-66, https://doi.org/10.24036/JESS.V4I1.233.
} 
Number 28/PUU-V/2007 implies that the criminal law enforcement process in Indonesia contains the ICJS mechanism for criminal law enforcement processes as a series of units from the investigation, prosecution, termination of cases to settlement at the correctional institution level. Thus, prosecutors' power in conducting investigations and investigations into criminal acts of corruption is based on positive law and judge jurisprudence and is factually recognized that prosecutors have the authority to carry out investigations and investigations into criminal acts of corruption.

Law No. 30 of 2014 concerning Government Administration was enacted because it has the Government Administration Bill's main objective, namely improving the quality of public services and government relations with the community. ${ }^{11}$ In consideration of the Judge of the Constitutional Court Decision No. 25/PUU-XIV/2016, Law No. 30 of 2014 is a translation of the Constitutional Court Decision No. 003/PUU-IV/2006 to prioritize the non-penal law enforcement process (outside the court), namely guided by the principle of ultimum remedium (application of criminal sanctions as a last resort). ${ }^{12}$ In determining a state loss, it is the Government Internal Supervisory Apparatus (APIP) which is based on PP No. 60 of 2008 concerning Government Internal Control Systems. APIP consists of BPKP, Inspectorate General or other names which functionally carry out internal supervision, Provincial Inspectorates, and Regency/City Inspectors. ${ }^{13}$ Article 2 Paragraph (1) and Article 3 of Law No.31 of 1999 concerning the Eradication of TPK have been subject to review in the Constitutional Court, namely in Case No. 003/PUU-IV/2006 and Case No. 25/PUU-XIV //2016. The test states that the applicant tests so that law enforcement against TPK should have real losses, not lost potentials preceded by acts against the law.

Law no. 30 of 2014 concerning Government Administration contains public law (namely criminal law) and private law (civil law), and state administrative law. ${ }^{14}$ This combination of laws creates a progressive impact on TPK law enforcement which implies that there are actions against the law that benefit oneself or another person or a corporation as referred to in Article 2 Paragraph (1) of the Corruption Act and the abuse of authority to benefit oneself or a corporation as referred to in Article 3 of the Corruption Act. Article 2 Paragraph (1) and Article 3 of the Corruption Act are vulnerable to multiple interpretations by law enforcement officials, which lead to the criminalization of government officials. ${ }^{15}$ In-Law no. 30 of 2014 concerning AP contains Article 17, Article 18, Article 19, Article 20, and Article 80, which are mutually related to the actions of government officials who are prohibited from abusing authority, supervision by APIP, and sanctions. In the administrative law concept, abuse of authority is always paralleled with the concept of detournement de pouvoir in the French legal system or abuse of power/misuse of power in English terms. ${ }^{16}$ There is an abuse of power in

\footnotetext{
11 Muhammad Yasin, et.all, 2017, Anotasi Undang-Undang Nomor 30 Tahun 2014 Tentang Administrasi pemerintahan, (Depok: Universitas Indonesia - Center for Study of Governance and Administrative Reform (UICSGAR))., pg.4

12 The Constitutional Court Decision No. 25/PUU-XIV/2016, pg. 111-112

13 Despan Heryansyah, "PROBLEMATIKA DISKRESI DALAM SISTEM HUKUM INDONESIA (STUDI TERHADAP UNDANG-UNDANG NO. 30 TAHON 2014)," Jurnal Yuridis, vol. 2, September 14, 2015, https://doi.org/10.35586/.V2I2.204.

14 DIKA YUDANTO NOURMA DEWI, "Sinkronisasi Undang-Undang Administrasi Pemerintah Dengan Undang-Undang Tindak Pidak Korupsi Dalam Penyelesaian Kasus Penyalahgunaan Wewenang Pejabat Pemerintah Di Indonesia," Serambi Hukum 10, no. 02 (January 30, 2017): 32-45, https://www.neliti.com/publications/163578/.

15 Ratna Nurhayati and Seno Wibowo Gumbira, "PERTANGGUNGJAWABAN PUBLIK DAN TINDAK PIDANA KORUPSI," Jurnal Hukum Dan Peradilan 6, no. 1 (March 31, 2017): 41, https://doi.org/10.25216/jhp.6.1.2017.41-66.

16 Philiphus M. Hadjon, et.all, 2012, Hukum Administrasi dan Tindak Pidana Korupsi Cetakan Kedua, (Yogyakarta: Gajahmada University Press), pg. 21-22.
} 
Law No. 30 of 2014 concerning Government Administration can result in the functioning of public law (criminal law), private law (civil law), and state administrative law. This provision functions in public law, namely when the abuse of power can become a criminal act of corruption that causes state losses (real cost). ${ }^{17}$ The law's function results in the abuse of authority, which results in losses to the state. The government apparatus/government officials must return the losses to the state. Then, the government administration system's functioning is related to the Government Administration Law, namely that offenders can be subject to administrative sanctions. ${ }^{18}$ There are real losses that are not potential losses or potential losses to the state. Hence the existence of Article 2 Paragraph (1) and Article 3 of Law No. 31 of 1999 concerning the Eradication of TPK means that there must be a definite and real loss of state finances to protect legal certainty for state administrators. Article 20 Paragraph (4) Law no. 30 of 2014 concerning Government Administration states that if there is an administrative error and there is a state loss, then the loss can be returned within a period often. This becomes the basis of examining reports or complaints from the public to law enforcement officials related to indications of a criminal act of corruption. First, an in-depth examination is carried out whether the act is an act of abuse of authority included in Article 17 of Law No. 30 of 2014 concerning Government Administration or including TPK. ${ }^{19}$

The prosecutor's authority is closely related to investigating criminal acts of corruption, namely the existence of a Cooperation Agreement (MoU) between the Indonesian Ministry of Home Affairs and the Indonesian Prosecutor's Office and the Indonesian Police regarding the Coordination of Government Internal Supervisory Apparatus (APIP) No. 119-49 of 2018, No. B-369/F/Fjp/02/2018 and No. B/9/II/2018. The MoU has a derivative of internal technical instructions at the RI Prosecutor's Office, namely the Letter of the Junior Attorney General for Special Crimes of the Republic of Indonesia No.B-765/F/Fd.1 / 04/2018 dated 20 April 2018 regarding Technical Guidelines for Handling Corruption Cases in the Investigation Stage. ${ }^{20}$

Based on these matters, the prosecutor has the authority to carry out the process of law enforcement, namely investigating alleged TPK then after the enactment of Law no. 30 of 2014 concerning Government Administration, law enforcement of non-criminal corruption allegations are not only judged by the element of corruption, which is in the form of acts against the law, however, it must also be considered that real state losses can be recovered from the results of state losses. In the view of the Indonesian Prosecutor's Office, the return of state losses is one of the benchmarks for assessing work performance.

2. Legal certainty for the investigation of the Pringsewu District Attorney's Office in coordination with the Government Internal Supervisory Apparatus or Aparatur Pengawas Internal Pemerintah (APIP) on the Return of State Losses for Alleged Corruption in Village Funds of Pekon Sukaratu

Legal certainty becomes the boundary line so that the government does not use the power they have to oppress the people. Legal certainty means the legal instruments of a country that can guarantee every citizen's rights and obligations. The principle of legal certainty is a principle that aims to respect the rights owned by a person based on a state administrative

\footnotetext{
${ }^{17}$ Aju Putrijanti and Lapon Tukan Leonard, "Kompetensi Peratun Untuk Memeriksa Unsur Penyalahgunaan Wewenang," Jurnal IUS Kajian Hukum Dan Keadilan 7, no. 1 (April 23, 2019): 107-27, https://doi.org/10.29303/ius.v7i1.605.

18 Enrico Parulian Simanjuntak, "PERKARA ADVOKASI PUBLIK PASCA BERLAKUNYA UNDANGUNDANG ADMINISTRASI PEMERINTAHAN (UUAP)," Jurnal IUS Kajian Hukum Dan Keadilan 6, no. 1 (April 27, 2018): 14, https://doi.org/10.29303/ius.v6i1.535.

19 Barhamudin Barhamudin, "Penyalahgunaan Kewenangan Pejabat Pemerintahan Dan Ruang Lingkupnya Menurut Undang-Undang Administrasi Pemerintahan," Solusi 17, no. 2 (May 1, 2019): 175-92, https://doi.org/10.36546/solusi.v17i2.171.

${ }^{20}$ Amru E. Siregar, SH, MH. (Interview), Kejaksaan Negeri Pringsewu, 5 May 2020.
} 
body or official decision. The principle of legal certainty, namely the principle in a state of law that prioritizes the foundation of statutory regulations, compliance, and justice in every policy of state administrators. The principle of legal certainty has two aspects, namely material law and formal law. Material law aspects are closely related to the principle of trust. This principle requires the respect of rights that have been obtained by a person based on a government decision even though the decision is wrong. In other words, for the sake of legal certainty, every decision issued by the government is not to be revoked. Of course, this legal certainty is related to determining the prosecutor's investigation in covering someone until the issuance of a judge's decision from the court or prosecutor's office.

The Pringsewu District Attorney's Team has examined 106 people for questioning and examined the Accountability Report to use village funds. Based on the Investigation Result Report dated 26 December 2018, the investigating team found an accountability report in the form of notes suspected to be not true. Based on the statements of several parties who were asked for the information, it turned out to be true. Furthermore, it was explained that the Activity Implementation Team or Team Pelaksana Kegiatan (TPK) had never managed the development activity budget at all because the Head of the Sukaratu Pekon directly managed the management. For calculating the volume of development work, based on the examination results that the Expert had calculated, there was a difference, namely in the amount of Rp 64.792.900. Based on the investigation team's information, there was an overpayment made by the Pekon Sukaratu party in developing the use of the Pekon Sukaratu Village Fund. ${ }^{21}$ Dalam kasus a quo, Kepala Pekon atau Kepala Desa dan Perangkat Pekon atau Perangkat Desa termasuk dalam subyek yang dilaporkan atau yang diadukan oleh masyarakat yang terdapat dalam MoU tersebut. ${ }^{22}$

It is true that the team of investigating prosecutors found a criminal act during the investigation and found a state loss. However, the Pekon Sukaratu treasurer had deposited the state loss into Pekon Sukaratu's treasury in the amount of Rp 254.132.100 on 13 December 13, 2018, it is also based on the letter of the Inspectorate of Pringsewu Regency number 700/959 / U.14 / 2018 dated 17 December 2018 regarding the results of the Inspectorate's follow-up to the Sukaratu pekon, Pagelaran sub-district, The contents of the letter were in the form of recovery of state financial losses by Pekon Sukaratu by depositing in Pekon Sukaratu's treasury of Rp 254.132.100 on 13 December $2018 .^{23}$ The deposit or return of state losses makes up the elements of Article 2 Paragraph (1) and Article 3 of Law no. 31 of 1999 (after being tested at the Constitutional Court with Decision No. 25/PUU-XIV/2016) is no longer fulfilled, and the investigation is terminated. Article 7 of the MoU regulates the coordination system between APIP and Law Enforcement Officials or Aparat Penegak Hukum (APH), namely the Indonesian Police and the Indonesian Prosecutor's Office, in handling reports of public complaints indicating criminal acts of corruption. APIP can coordinate the findings of indications of suspected corruption to the Prosecutor's Office or the Police and the Attorney General's Office, and the Police. If they find administrative errors, they can coordinate with the Attorney General's Office and the Police. ${ }^{24}$ The Inspectorate checks the case with an Inspection Result Report or Laporan Hasil Pemeriksaan (LPH) by finding a state loss of Rp. 254.132.100. ${ }^{25}$ Pringsewu District Inspectorate Letter number 700/959/U.14/2018 dated 17 December 2018 concerning the results of the Inspectorate's follow-up to the Sukaratu district of Pagelaran sub-district, which contained the contents of

\footnotetext{
21 Ibid.

${ }^{22}$ Ibid.

${ }^{23} \mathrm{Ibid}$.

${ }^{24}$ Andi Purwanto, ST, MT, (Interview), Inspektorat Kabupaten Pringsewu, 6 May 2020.

25 Ibid.
} 
the letter in the form of recovering state financial losses by Pekon Vooratu by making deposits to the Pekon treasury. Sukaratu of Rp 254.132.100 on 13 December 2018. ${ }^{26}$

In the a quo case, the Pringsewu District Prosecutor's Office coordinated with APIP, namely the Pringsewu District Inspectorate Letter No. B-1432/N.8.16.8/Fd.1/9/2018 dated 28 September 2018 regarding the coordination of the implementation of the Pekon Sukaratu investigation, Pagelaran District. The return of state losses in the a quo case is one of the definite legal actions in Law no. 30 of 2014 concerning AP, especially in Article 20 Paragraph (4) and the Decision of the Constitutional Court No. 25/PUU-XIV/2016, which granted the review of Article 2 Paragraph (1) and Article 3 of Law No. 31 of 1999 concerning the Eradication of Corruption Crimes must also pay attention to the real loss of state finances (real lost), not only potential lost, furthermore there is also a Memorandum of Understanding (MoU) between the Indonesian Ministry of Home Affairs and the Indonesian Attorney General's Office and the Indonesian Police Number 119-49 of 2018, Number B$369 / \mathrm{F} / \mathrm{Fjp} / 02 / 2018$ and Number B/9/II/2018 as well as contained in the technical instructions contained in Letter of the Deputy Attorney General for Special Crimes of the Republic of Indonesia No. B-765/F/Fd.1/04/2018, dated 20 April 2018, regarding the Technical Guidelines for Handling Corruption Cases, the Investigation Stage, which prioritizes the return of state losses by the parties, is a law enforcement action that can consider further law enforcement processes.

Based on these matters, although there have been elements of criminal incidents in the investigation stage of the Pringsewu District Prosecutors' team, and there has also been a refund of state losses by the Pekon Sukaratu Treasurer, it is an integrated ICJS system based on the prevailing laws and regulations and contains legal certainty.

\section{Conclusion}

Prosecutors have the authority to conduct investigations into criminal acts of corruption based on Article 30 Paragraph (1) letter d of Law no. 16 of 2004 concerning the RI Attorney General's Office. After the passing of Law no. 30 of 2014, concerning Government Administration has implications for the law enforcement system that prioritizes the return of state losses due to allegations of corruption by the parties. After the passing of Law no. 30 of 2014 concerning Government Administration, especially in Article 20 Paragraph (4) in line with the Decision of the Constitutional Court No. 25/PUU-XIV/2016, which granted the applicant's petition by canceling the word "could" in Article 2 Paragraph (1) and Article 3 of Law No. 31 of 1999 concerning the Eradication of Corruption Crime so that the provisions of Article 2 Paragraph (1) and Article 3 of Law no. 31 of 1999 concerning the Eradication of Corruption Crimes must be interpreted as a real loss to the state (real lost) not a potential loss to the state (potential lost). Furthermore, the implication is that the prosecutor's authority in investigating criminal acts of corruption not only finds elements of corruption in the form of acts against the law, but must also find real losses to the state so that the elements of corruption are fulfilled. The power of prosecutors in conducting investigations has been fulfilled based on the prevailing laws and regulations. The investigating prosecutors conducting investigations into cases of suspected corruption have been fulfilled.

The need for amendments to laws systematically and synchronously carried out by lawmakers regarding the authority of prosecutors to carry out investigations because investigation and investigation are an inseparable unit of an integrated system of law enforcement for criminal acts. There needs to be socialization and in-depth understanding for prosecutors regarding the authority of prosecutors as investigators of corruption and the Government Internal Supervisory Apparatus or Aparatur Pengawas Internal Pemerintah

\footnotetext{
${ }^{26}$ Ibid.
} 
(APIP) in carrying out investigations and calculating state financial losses properly due to the process of the ICJS law enforcement system, especially corruption that has potential lost and real lost by prioritizing the principle of ultimum remedium (application of criminal sanctions as a last resort) which can prioritize the principle of legal certainty and justice so as not to injure human rights.

\section{Bibiliography}

\section{A. Book}

M. Hadjon, Philiphus, et.all, 2012, Hukum Administrasi dan Tindak Pidana Korupsi Cetakan Kedua, Gajahmada University Press, Yogyakarta.

Yasin, Muhammad, et.all, 2017, Anotasi Undang-Undang Nomor 30 Tahun 2014 Tentang Administrasi pemerintahan, Depok: Universitas Indonesia - Center for Study of Governance and Administrative Reform (UI-CSGAR).

\section{B. Journal}

Barhamudin, Barhamudin. "Penyalahgunaan Kewenangan Pejabat Pemerintahan Dan Ruang Lingkupnya Menurut Undang-Undang Administrasi Pemerintahan." Solusi 17, no. 2 (May 1, 2019): 175-92. https://doi.org/10.36546/solusi.v17i2.171.

Bolifaar, Andhy Hermawan, and Henry Dianto Pardamean Sinaga. "Managing Evidence of Tax Crime in Indonesia: An Artificial Intelligence Approach in Integrated Criminal Justice System." A $Y E$ $R$ JOURNAL 27, no. 1 (October 5, 2020): 143-58. https://doi.org/10.1445/AYERJOURNAL.V27I1.128.

Heryansyah, Despan. "PROBLEMATIKA DISKRESI DALAM SISTEM HUKUM INDONESIA (STUDI TERHADAP UNDANG-UNDANG NO. 30 TAHON 2014)." Jurnal Yuridis. Vol. 2, September 14, 2015. https://doi.org/10.35586/.V2I2.204.

Kurnia, Vani, Sahuri Lasmadi, and Elizabeth Siregar. "Tinjauan Yuridis Terhadap Tugas Dan Kewenangan Jaksa Sebagai Penyidik Dalam Perkara Tindak Pidana Korupsi 2020." Pampas Journal of Criminal Law 1, no. 3 (2020): 1-11. https://onlinejournal.unja.ac.id/Pampas/article/view/11084.

Manao, Disiplin F. "Penyelesaian Penyalahgunaan Wewenang Oleh Aparatur Pemerintah Dari Segi Hukum Administrasi Dihubungkan Dengan Tindak Pidana Korupsi." Jurnal Wawasan Yuridika 2, no. 1 (March 31, 2018): 1. https://doi.org/10.25072/jwy.v2i1.158.

Mumu, Gratia Debora. "KEWENANGAN JAKSA SEBAGAI PENYIDIK TINDAK PIDANA KORUPSI 1 Oleh: Gratia Debora Mumu 2." LEX ADMINISTRATUM. Vol. 4, March 16, 2016. https://ejournal.unsrat.ac.id/index.php/administratum/article/view/11503.

NOURMA DEWI, DIKA YUDANTO. "Sinkronisasi Undang-Undang Administrasi Pemerintah Dengan Undang-Undang Tindak Pidak Korupsi Dalam Penyelesaian Kasus Penyalahgunaan Wewenang Pejabat Pemerintah Di Indonesia." Serambi Hukum 10, no. 02 (January 30, 2017): 32-45. https://www.neliti.com/publications/163578/.

Nurhayati, Ratna, and Seno Wibowo Gumbira. "PERTANGGUNGJAWABAN PUBLIK DAN TINDAK PIDANA KORUPSI.” Jurnal Hukum Dan Peradilan 6, no. 1 (March 31, 2017): 41. https://doi.org/10.25216/jhp.6.1.2017.41-66.

Panjaitan, Marojahan. "PENYELESAIAN PENYALAHGUNAAN WEWENANG YANG MENIMBULKAN KERUGIAN NEGARA MENURUT HUKUM ADMINISTRASI PEMERINTAHAN." Jurnal Hukum IUS QUIA IUSTUM 24, no. 3 (July 2017): 431-47. https://doi.org/10.20885/iustum.vol24.iss3.art5.

Putrijanti, Aju, and Lapon Tukan Leonard. "Kompetensi Peratun Untuk Memeriksa Unsur Penyalahgunaan Wewenang." Jurnal IUS Kajian Hukum Dan Keadilan 7, no. 1 (April 23, 2019): 107-27. https://doi.org/10.29303/ius.v7i1.605.

Sahlan, Mohammad. "Kewenangan Peradilan Tipikor Pasca Berlakunya Undang-Undang No. 30 
Tahun 2014 Tentang Administrasi Pemerintahan." Arena Hukum 9, no. 2 (2016): 166-89. https://doi.org/10.21776/ub.arenahukum.2016.00902.2.

Simanjuntak, Enrico Parulian. "PERKARA ADVOKASI PUBLIK PASCA BERLAKUNYA UNDANG-UNDANG ADMINISTRASI PEMERINTAHAN (UUAP)." Jurnal IUS Kajian Hukum Dan Keadilan 6, no. 1 (April 27, 2018): 14. https://doi.org/10.29303/ius.v6i1.535.

Sutrisno, Sutrisno, and Ibnu Artadi. "IMPLEMENTASI PENEGAKKAN HUKUM TINDAK PIDANA KORUPSI PASCA BERLAKUNYA UU NO 30 TAHUN 2014 TENTANG ADMINISTRASI PEMERINTAHAN." HERMENEUTIKA: Jurnal Ilmu Hukum 3, no. 2 (September 28, 2019). https://doi.org/10.33603/hermeneutika.v3i2.2600.

Yuliastuti, Eka, and Iain Metro. "AL-WATHAN: Jurnal Ilmu Syariah PROBLEMATIKA YANG DIHADAPI JAKSA DALAM PENYIDIKAN TINDAK PIDANA KORUPSI (Studi Kasus Pada Kejaksaan Negeri Karanganyar)." Al-Wathan: Jurnal Ilmu Syariah. Vol. 1, January 8, 2020. https://jurnal.stisda.ac.id/index.php/wathanDOI:https://doi.org/.

Zulkarnaen, Zulkarnaen, Zainal Asikin, and Amiruddin Amiruddin. "Penyalahgunaan Wewenang Dalam Tindak Pidana Korupsi Setelah Berlakunya UU No. 30 Tahun 2014 Tentang Administrasi Pemerintahan." JESS (Journal of Education on Social Science) 4, no. 1 (June 1, 2020): 53-66. https://doi.org/10.24036/JESS.V4I1.233.

\section{Regulation}

The Constitutional Court Decision No. 28/PUU-V/2007.

The Constitutional Court Decision No No. 25/PUU-XIV/2016. 